\title{
CORRECTION
}

Nutrition in acute and chronic diseases

\section{Correction to: Assessing lean tissue by bioelectrical impedance analysis pre hemodialysis underestimates the prevalence of sarcopenia in maintenance hemodialysis patients}

Minmin Wang (D), Lin Liu (D), Xiaogang Shen (D), Yiwen Li (D) and Qiang He (D)

(c) The Author(s), under exclusive licence to Springer Nature Limited 2021

European Journal of Clinical Nutrition (2022) 76:334; https://doi.org/10.1038/s41430-021-00966-7

Correction to: European Journal of Clinical Nutrition https://doi.org/ 10.1038/s41430-020-00835-9

Unfortunately, an error occurred in the author affiliations. The first address was incomplete. The complete affiliation is given below:

Department of Clinical Medicine, Medical College of Soochow University, Suzhou, P.R. China.

The original article has been corrected.

\section{ADDITIONAL INFORMATION}

Correspondence and requests for materials should be addressed to Q.H.

Reprints and permission information is available at http://www.nature.com/ reprints

Publisher's note Springer Nature remains neutral with regard to jurisdictional claims in published maps and institutional affiliations. 